\title{
PRINCIPLES OF HIGHER EDUCATION DEVELOPMENT IN WORKS OF RUSSIAN PHILOSOPHERS AND SCIENTISTS OF 20TH CENTURY
}

\author{
PRINCIPIOS DE DESARROLLO DE LA EDUCACIÓN SUPERIOR EN TRABAJOS DE \\ FILÓSOFOS Y CIENTÍFICOS RUSOS DEL SIGLO XX
}

\section{PRINCÍPIOS DO DESENVOLVIMENTO DA EDUCAÇÃO SUPERIOR EM OBRAS DE FILÓSOFOS E CIENTISTA DO RUSSO DO SÉCULO XX}

Olga A. Volnyakova

Russian Technological University - Rússia

\author{
Oleg G. Arapov \\ Peoples' Friendship University of Russia (RUDN University) - Rússia
}

\author{
Elmira A. Arapova \\ Russian Technological University - Rússia
}

Denis V. Solodukhin

Russian Technological University - Rússia

\begin{abstract}
Introduction: the article is devoted to research of higher education various aspects, results of its recognition in national scientific and philosophical thought of $20^{\text {th }}$ century are presented, connection with common European trends of higher school is detected. Views of popular Russian philosophers and scientists who made their contribution into ideologic basis and principles of University education in Russia in $20^{\text {th }}$ century are considered. Materials and methods: Methods are based on research traditions of humane knowledge: philosophical-anthropologic approach to problems of human existence, comparative method of educational problems consideration in connection with various cultural and historical contexts of human existence development, comparative-historical method. Besides that phenomenological and hermeneutic research methods are reflected. Basis, contents, goals and targets of educational system including University education and connection of education with actual inquiries of contemporary human being and society are detected and philosophically comprehended. Results of research: It is presented in the article that major approaches to education and results of its comprehension by Russian thinkers comprise content unity and resonate with actual problems of its structure and contents in terms of modern world including Russian reality. Therefore the idea of necessity of optimal combination of natural scientific, special and philosophical knowledge in educational system is substantiated. Such approach allows to develop education in terms of humanitarian values, facilitates the formation of morally and spiritually oriented and socially responsible personality of the specialist, exercising reasonable world view. Discussion and conclusion: received results may be used in order to exercising the principles of higher education development in
\end{abstract}


terms of contemporary challenges basing on principle of succession and keeping the greatest cultural traditions, and also for strategical planning of University educational programs.

Keywords: Higher Education; Philosophy of education; Russian thinkers; New moral imperative; University; Humanities.

Resumen: Introducción: el artículo está dedicado a la investigación de la educación superior en diversos aspectos, se presentan los resultados de su reconocimiento en el pensamiento científico y filosófico nacional del siglo XX, se detecta la conexión con las tendencias europeas comunes de la escuela superior. Se consideran las opiniones de los filósofos y científicos rusos populares que hicieron su contribución a la base ideológica y los principios de la educación universitaria en Rusia en el siglo XX. Materiales y métodos: los métodos se basan en tradiciones de investigación del conocimiento humano: enfoque filosófico-antropológico de los problemas de la existencia humana, método comparativo de consideración de problemas educativos en relación con diversos contextos culturales e históricos del desarrollo de la existencia humana, método comparativo-histórico. Además de eso se reflejan los métodos de investigación fenomenológica y hermenéutica. Se detectan y comprenden filosóficamente las bases, los contenidos, los objetivos y las metas del sistema educativo, incluida la educación universitaria y la conexión de la educación con las investigaciones reales del ser humano y la sociedad contemporáneos. Resultados de la investigación: se presenta en el artículo que los principales enfoques de la educación y los resultados de su comprensión por parte de los pensadores rusos comprenden la unidad de contenido y resuenan con los problemas reales de su estructura y contenido en términos del mundo moderno, incluida la realidad rusa. Por lo tanto, se confirma la idea de la necesidad de una combinación óptima de conocimiento científico natural, especial y filosófico en el sistema educativo. Tal enfoque permite desarrollar la educación en términos de valores humanitarios, facilita la formación de la personalidad moral y espiritualmente orientada y socialmente responsable del especialista, ejerciendo una visión del mundo razonable. Discusión y conclusión: los resultados recibidos pueden usarse para ejercer los principios del desarrollo de la educación superior en términos de desafíos contemporáneos basados en el principio de sucesión y el mantenimiento de las mayores tradiciones culturales, y también para la planificación estratégica de los programas educativos de la Universidad.

Palabras clave: Educación superior; Filosofía de la educación; Pensadores rusos; Nuevo imperativo moral; Universidad; Humanidades.

Resumo: Introdução: o artigo é dedicado à pesquisa do ensino superior em vários aspectos, são apresentados os resultados do seu reconhecimento no pensamento científico e filosófico nacional do século XX, sendo detectada conexão com as tendências europeias comuns do ensino superior. Considerações de filósofos e cientistas russos populares que deram sua contribuição à base ideológica e aos princípios do ensino universitário na Rússia no século XX são consideradas. Materiais e métodos: Os métodos são baseados em tradições de pesquisa do conhecimento humano: abordagem filosófico-antropológica dos problemas da existência humana, método comparativo de consideração de problemas educacionais em conexão com vários contextos culturais e históricos do desenvolvimento da existência humana, método histórico-comparativo. Além disso, são refletidos os métodos de pesquisa fenomenológica e hermenêutica. A base, o conteúdo, as metas e os objetivos do sistema educacional, incluindo o ensino universitário e a conexão da educação com investigações reais do ser humano e da sociedade contemporâneos, são detectados e compreendidos filosoficamente. Resultados da pesquisa: É apresentado no artigo que as principais abordagens da educação e os resultados de sua compreensão pelos pensadores russos compreendem a unidade de conteúdo e ressoam com problemas reais de sua estrutura e conteúdo em termos do mundo moderno, incluindo a realidade russa. Portanto, a ideia da necessidade de uma combinação ótima de conhecimentos científicos, especiais e filosóficos naturais no sistema educacional é fundamentada. Essa abordagem permite desenvolver a educação em termos de valores humanitários, facilita a formação de personalidade moral e espiritualmente orientada 
e socialmente responsável do especialista, exercendo uma visão de mundo razoável. Discussão e conclusão: os resultados recebidos podem ser utilizados para o exercício dos princípios do desenvolvimento do ensino superior em termos de desafios contemporâneos, baseados no princípio da sucessão e na manutenção das maiores tradições culturais, e também no planejamento estratégico dos programas educacionais da Universidade.

Palavras-chave: Ensino superior; Filosofia da educação; Pensadores russos; Novo imperativo moral; Universidade; Ciências humanas.

\section{Introduction}

Modern approaches to education, including philosophical ones, aim at finding solutions to various theoretical and practical problems of higher education. Among the most pressing are the questions of the place and role of education in the realities of modern culture; the real meaning and value of education beyond the narrow practical needs; the ways of its further development; and, finally, the need and ways to form a new ideal of scholarship that meets the current intellectual and spiritual needs of individuals and society in general. These problems have long been at the intersection of interests of many intellectual fields, as alongside teachers and philosophers they were often addressed by philosophically oriented scientists.

The development of modern culture, the real needs of society in finding ways for the future civilizational development of humankind impose special requirements to education, which should strive not only to train single-discipline specialists in various fields of professional activity, but also to form and bring up a spiritually and morally oriented personalities, capable of meeting the current challenges (Gharawi, Bidin \& Choo, 2020). They study material allows to address many problems of higher education and to work out strategies for its development.

The paper draws on the principles of higher education development, including university education, that were formulateB in the works of Russian philosophers and philosophically thinking scientists of the 20th century.

The purpose of the article is to consider the views of Russian scientists on the organization and content of university education and to justify their relevance for the present moment. The main objectives of the study are: to substantiate the need to synthesize different area and lines of scientific thought within the university education system; to reveal the optimal combination of scientific, expert and philosophical knowledge in the education 
system; to show that success in solving many modern problems highly depends on the understanding of the importance of strengthening the connection between science and the moral and spiritual foundations of human life and society; to actualize the issue of increasing the role of humanities in training the scientist as a socially responsible individual; to define the role of philosophy as a scientific and academic discipline indispensable for actual development of civilization. It is this kind of approach that makes it possible to develop education in the context of humanistic values, to contribute to the formation of the expert's personality, to develop his conscious and socially responsible outlook and to form a new ethics and spirituality.

\section{Literature review}

The scientific literature deals with the problem of interaction between universities and schools in terms of the study of science in an "informal environment" (National Research Council, 2009; Halversen \& Tran, 2010). In higher education, the training of beginners is about the transfer of experience through practical research with experienced academic tutors. Some authors like Gagaev and Gagaev (2008) and Lobanova (2007) examine Russian philosophical and pedagogical teachings of 18-20 centuries. As a rule, all researches of this type deal only with the secondary education, leaving the higher education aside. The problems of higher education are considered in the paper by Arapov, Arapova, Volnyakova and Solodukhin (2018).

According to Halversen and Tran (2010), the development of a partnership between expert communities and students will make it possible to form skilled practical specialists. Saxman, Gupta and Steinberg (2010) discuss the interrelationship between schools at different levels, describing the experience of collaboration between the New York Interactive Science Center and a local college, which allowed both to use their strengths to train school teachers. Avis Masuda describes how the aspiring teacher can benefit from the partnership between schools and universities (Masuda, 2014). Morrison and Estes (2007) have shown that involving school teachers in scientific problem-solving experiences proves fruitful.

Many articles address the problem of philosophy as a mandatory scientific and academic discipline, as well as its worldview role in the development of modern civilization (Hicks \& Holbrook, 2019; Lazutina, Tempel \& Tempel, 2017). Arapov and others (2016) raised the problem of rationality of philosophical knowledge. 
Under the conditions of an increased tendency towards the distant education, the problem of the scientist as a teacher is discussed with the special focus on the increasing role of the teacher and the demand for face-to-face communication with the students (Margolis, 2007; Ryan et al., 2017; Vasilevska, Rivza, Alekneviciene and Parlińska, 2017; National Research Council, 1996; Jusuf, Herwany, Kurniawan \& Gunardi, 2020). Löfström and Pyhältö (2017), Berbegal-Mirabent, Mas-Machuca and Marimon (2018) address ethical issues and aspects of scientific supervision and education.

The problems of young scientists' independent work, their motivation and willingness to meet the unknown are discussed in articles by Faber, Hardin, Klein-Gardner and Benson (2014), as well as in the paper by Scoles and others (2019). McLean and Price (2019) dwell on the issue of forming professional identity of the aspiring academic teachers.

The problems of the "marketization" of education and the autonomy of universities are discussed in an article by Williams (1991), who points out the threat for universities of losing their role as independent centers of critical research, if the selective funding is limited to those that can bring commercial benefits. Bendixen and Jacobsen (2017) note the destructiveness of replacing the commitment to quality with market "standards", which means that external control over higher education. Hammarfelt, de Rijcke and Wouters (2017) refer to the origins of "scientometrics" as attempts to contrast the quality of higher education and science with the ideas of eugenics that tended to distinguish "great men".

Numerous papers are devoted to the management of science as well as its interaction with society in relation to the problems of democracy and the demands of the market. In an article by Conceição, Ávila, Coelho and Costa (2019) the question of changing the balance between goals related to democracy on the one hand and economic competitiveness on the other is considered.

\section{Materials and Methods}

The methods used in this work are based on the research traditions of the humanities, primarily on the philosophical and anthropological approach to the problems of human life, which largely determined the development of philosophical and humane knowledge in the 20th century. The authors of the article widely use the comparative method of considering the problems of education in connection with various cultural and historical contexts of its development. The comparative-historical method is also among the major ones in the study. 
The paper also embraces the phenomenological and hermeneutic methods that allow to identify and interpret philosophically the very foundations, essence, goals and objectives of the education system, including the university system, as well as the connection of education with the real needs of individuals and society in general.

\section{Results}

The education have long been the object of cognition of Russian philosophers, as well as scientists, reaching in their studies to the level of philosophical understanding of the development of education and implementing their ideas in practice. By the beginning of the 20th century in Russian culture and academa there was a tradition of understanding the specifics of higher education as an area that forms an expert- researcher and a comprehensively developed personality.

Russian scientist and chemist Mendeleev (1905), who worked at St. Petersburg University for more than thirty years, used his pedagogical experience to continue the tradition of philosophical understanding of the problems of secondary and especially higher education laid down earlier by both Russian and foreign thinkers. In the first half of the 20th century, such scientists and philosophers as Vernadsky (1993, 2010), Ukhtomsky (2008) and Hessen (1995) came up with a number of ideas representing a new experience in understanding the essence of education and its purpose in connection with the changing historical conditions for the development of Russian and world culture. They believed that the process of transforming a Russian university must not include a radical shift away from historical soil, from values and meanings that support educational processes, including a humane orientation. The second half of the 20th century confronted humankind with the challenges that determined the urgent need to develop more progressive strategies for the evolution of civilization, as they marked the significant exhaustion of the means of development that have served it during the past centuries. It is driven by the new global problems, primarily environmental, and directly related problems of the further development of the scientific and technical sphere of culture. The approaches to these challenges, including those of the education system, were examined in the works of Mamardashvili (1990a, 1990b).

In 1905, "The Cherished Thoughts" by Dmitry Ivanovich Mendeleev (1834-1907), a Russian chemist, and an encyclopedic scientist, was published. In this book, he gives a historical overview of the formation and development of the educational system from Ancient 
Greece and Rome to the beginning of the 20th century, when universities continue to play a paramount role, serving as a model for all other higher educational institutions and being cradles of specialization and philosophical strand of higher education.

Mendeleev (1995) emphasizes the interconnectedness of government activities and industrial development with educational issues and argues that where they are not developed, there is no demand for higher education; an educated person will find his place when an educated society will need him, otherwise "wit works woe". The connection of education with the real needs of society is not only in the training of single-discipline specialists in a particular field of production or other practical activities. Educated people should be prone to free self-determination and productive and creative activity in the world, in the realities of modern economic systems and social structures.

Mendeleev (1995) comes up with an interesting idea that primary and secondary education pursues mainly personal development, while higher education is about public and state development. He dialectically connects the single and the general, the individual and the social. Mendeleev (1995) said that the personal precedes the public as childhood precedes maturity. "Primary and even secondary and general education have to deal mainly with words, while higher education has to deal with deeds, with life, with social, so to speak, nonindividual relationships". Thus, Mendeleev (1995) demonstrates a public approach to the issue of education, noting that "a man is all the more perfect, as he is more useful for a wider range of public, state and global interests".

Already at the beginning of the 20th century, the scientist notes two historical changes that have occurred in higher education. He means the wider accessibility of education, in contrast to the former division of society into classes, as well as changes regarding the content of education: formerly it was considered possible to cover the entire body of knowledge of the time, but now education is inevitably specialized. According to Mendeleev (1995), such changes force us to look for new approaches to the content of education, but the principles laid down by predecessors must be preserved. One of the most important is the question of the optimal combination of natural sciences and philosophical knowledge. He believes that a young man at the age of 17 is already capable of understanding the philosophical principles vital for higher education. He points out that the whole point of higher education institutions is in the optimal combination of natural science and humane knowledge, in combining the abstract-infinite with concrete reality. 
Mendeleev (1995) argues that only teaching philosophy and other abstract sciences in combination with special practical disciplines gives confidence in the result, which is that the university must educate people who can predict the future based on the past and the present. Mendeleev (1995) writes that higher institutions should educate people who "can then independently step into the unknown, inquisitive, possessing all the basic methods necessary to reach yet unknown areas of knowledge...". Each new generation has to surpass the previous one, as this is the foundation of progress.

He supported universities as a form of organization of higher education, while emphasizing that this should also apply to technical educational institutions that had to be united in polytechnic institutes. One of the arguments was that at universities, students are not only influenced by professors, but, communicating with friends of various specialties, thus receiving a wide range of education.

Mendeleev's whole life was associated with scientific and pedagogical activity. He was a teacher in a gymnasium; at the age of 23 he began to lecture at St. Petersburg University, and was engaged in scientific work. He knew how to be a philosopher and, separating particulars from the general, introduced the depth of generalized provisions even into tasks of a purely practical nature. The main qualities of Mendeleev-the-scientist were selflessness and the desire to reach truth, not thinking about practical benefit or career progression. He argued that truth is not hidden from people, it is scattered among us, all over the world, it can be sought everywhere: in chemistry, in mathematics, in physics, in history, and in linguistics.

Russian philosopher and theorist of pedagogical thought Sergey Iosifovich Hessen (1887-1950) believed that education cannot be considered either as a simple acquisition of information, or as a formal development of the ability to think. The purpose of education is to introduce a person to culture. For Hessen (1995), the concepts of education and culture coincide. In his understanding, an educated person is a person who "soaked up all cultural values, that is, owns the method of scientific thinking, understands art, knows the law, has an economic set of min". At each stage of education - pre-school, school, college, university - a person gradually discovers the content of cultural values and actively masters them, becoming a person.

Higher or university education is the final stage of scientific education. The main task of scientific education is to teach the method of perceiving the truth, because the content of scientific knowledge is changing, but the method itself remains unchanged. According to 
Hessen (1995), "a method is the soul of knowledge, its life, as it creates individual scientific systems". The fundamental role in scientific education is played by teachers and lecturers. The philosopher believes that "one can master the method of scientific knowledge only by observing it in his living work. The method is transmitted not via books, but by infection, by direct transmission from person to person" (Hessen, 1995). During the classes, the teacher demonstrates the application of the scientific method, posing a problem for students, answering their questions, resolving their difficulties in understanding scientific knowledge; and only such "vigilance of thought" introduces the student to the scientific method of cognition and sets his "soul in a certain scientific way" (Hessen, 1995). This is not so much a psychological state as a "discovery" of a superpersonal, transcendental principle to which a person submits as to something obligatory.

At the university, scientific education is already carried out as an inextricable unity of research and teaching. The teacher is an active researcher, scientist; he teaches to the best of his scientific work. A student at the university is a participant in the research work of the teacher and an aspiring scientist himself. At the stage of university education, a completely different didactics is in place. While at the previous stages of scientific education it was necessary to know the means that best teach the scientific method, then at the stage of the scientific course, didactics is reduced to university policy (Hessen, 1995), i.e. the principles of organization of university education, which will best ensure the continuity of scientific creativity.

Hessen (1995) formulates three basic principles of university organization: the completeness of scientific knowledge, the freedom of teaching and learning, and selfgovernment.

The first principle assumes the completeness of the knowledge presented at the university. The student is being accustomed to consider his area of scientific interest in relation to other sciences. The completeness of science "destroys the one-sidedness of thinking, which every specialist is inclined to, and provides a wide outlook and tolerance, which are the conditions for living scientific creativity" (Hessen, 1995).

The second principle - the freedom of teaching and learning - is a natural element of the university. University teaching should be regarded as reporting the results of one's research. Hessen (1995) notes that traditional forms of teaching - lectures and seminars serve in the best way the task of teaching a scientific method and involving students in independent research. During the lecture, the scientist does not simply expound the results of 
his research, but shows the way (the method) of obtaining them. "Therefore, all objections to the lecture system of teaching, emphasizing the passivity of students during lectures, nonattendance by students, their uselessness next to good textbooks, etc., only indicate a decline in the scientific spirit at the university, which really leads to degeneration of lectures into a simple exposition of a certain 'sum of information"” (Hessen, 1995).

The third principle of the organization of the university is the principle of selfgovernment, or autonomy: the university independently determines the subjects of teaching, curricula, the educational and auxiliary organizations, the election of professors and teachers, endowment with academic degrees.

According to Hessen (1995), these principles of university organization contribute to the maximum extent to the realization of its mission, namely to be the keeper and creator of scientific knowledge.

A similar approach was developed by the prominent Russian philosopher Ivan Aleksandrovich Ilyin (1883-1954) and Alexei Alekseevich Ukhtomsky (1875-1942), a wellknown physiologist, thinker, creator of the "theory of dominant". Both avocate the scientific freedom and responsibility of students. Freedom and responsibility are the cornerstones of the highest level of education. The first is independence from all requirements and restrictions alien to science, including "political and social servility", as well as from any pressure on the conscience and mind of the researcher. At the same time, of great importance is a "sense of responsibility", submission to the requirements of the subject and research conscience (Ilyin, 2017).

The mission of the scientist is to awaken the interest in the very subject under study, to transfer research experience and introduce students to the practice of independent research. The associate professor of the university is to provide a vivid encounter of his students with a scientific subject. In teaching science, personal contact and practical exercises (seminars, colloquiums, laboratory work, etc.) are indispensable. Here, the most important is the "method", as the higher education engages students in it; only the method can lead to the truth (note the direct correspondence to Hessen's thought (1995)).

In acquiring research skills, an apperceptive background between the teacher and the student is necessary; both sides are important at once. According to Ukhtomsky (2008), the most aspiring scientist develops an intuitive craving for a certain teacher that is driven by the professional and personal qualities of both persons. To be mature student have to be also independent. 
A mentor-scientist is an enthusiastic, dedicated researcher-worker, with an expressed will towards truth, who recognizes the limits of his knowledge, who is revers the "secrets of the world", who sees a vocation in deciphering a certain "God's hieroglyph" and who is not alien to anything, including philosophy (Ilyin, 2017).

Vladimir Ivanovich Vernadsky (1863-1945), the prominent Russian scientist, philosopher-naturalist, reflected on the matter of education in connection with various aspects of global evolutionary processes and the problems of culture: scientific and technological progress and its consequences; humanization of life and the role of science in the civilizational development of mankind. He formulated the most important principles of the ethos of the noosphere, which have to guide a person who is morally responsible for the fate of the whole universe in hisher scientific work and practical activities. According to Vernadsky (1993), the noosphere is "a biosphere processed by scientific thought, prepared by hundreds of millions, maybe billions of years by the process that created Homo sapiens faber...".

In a situation where the rate of changes in Nature, which are technogenic in their essence, has increased over time, the problem of self-awareness also increases. Individuals have to understand the purpose of their existence, which in general determines the very logic of being, its idea and meaning. In this regard, Vernadsky $(1993,2010)$ poses the problem of the development and dissemination of education that would meet the spirit of the current historical period. The formation of a deep, conscious and responsible person and social societies, guided by high moral principles, is an equally necessary prerequisite of the noosphere, as well as creative scientific work. Being a theoretical scientist and university teacher, initiator of public education, one of the organizers of academic and university science, Vernadsky $(1993,2010)$ wanted to solve not only theoretical, but also practical issues of education at all its levels. He entrusted higher education with a mission to be a center for the development, preservation and dissemination of scientific knowledge and enlightenment. Universities must introduce the young generation of scientists and students to high standards of scientific culture, principles and norms (including ethical ones) of scientific activity. In addition, university science, based on the creative union of teachers and students, was conceived by him as an opportunity for independent scientific search, as a place of crystallization and development of new research projects.

A university is a sphere of special attitude towards a person. The thinking person represents the vital basis of the noospheric development of the entire cosmosystem, and 
therefore it is an unconditional value. Scientific thought is something derived from the human person, obsessed with the search for truth and producing truth. As Vernadsky (2010) pointed out, in the scientific community "those individuals come forward that stand out sharply from the crowd either by the strength of their mind, or by their clarity, or breadth of thought, willpower, intuition, creativity... And these outstanding people cannot be replaced in most scientific discoveries by the collective work of many".

This also applies to education: here the personality of a mentor-teacher also plays a special role, as he becomes a living example of committed service to the goals and objectives of cognition, the ideals of science and, finally, the fundamental ideas of the civilizational development of humankind. In the educational process of youth, the results achieved by science at a given time are transferred, the skills of scientific work are instilled, the foundations of future teaching are laid, with scientists being the teachers of humanity. For this reason, Vernadsky $(1993,2010)$ insisted that the latest scientific developments should be introduced into the education system: the educational process should not lag behind the real development of scientific knowledge. For its part, universities must provide the opportunity for gifted and interested individuals to learn and increase knowledge; freely express the creative possibilities of the mind. At the same time the level of organization of collective scientific work of teachers and students has to be increased.

According to Vernadsky $(1993,2010)$, people whose life-long activity takes place in the scientific and educational sphere, must develop a special type of morally oriented relations and behavior, a sufficiently high quality of sociality, inaccessible to the masses. The participants in the scientific community are united by such highest cultural values as truth, blessing, justice, honesty and progress. The scientific world, the world of the University, in view of this circumstance, is more in line with the ideal of a composite (cf. the notion of sobornost') humanity, which includes not only the living scientists, but all the preceding generations of prominent minds, enlightenment scholars, whose contribution is very tangible and amounts to heritage and the very essence of intellectual culture.

In addition, such an organic social integrity presupposes a rational, and therefore careful attitude to the "living matter" of the planet as the material basis of the noosphere. Vernadsky $(1993,2010)$ believes that the processes of the biosphere will, over time and to an increasing degree, begin to obey the laws established for them by the scientific mind. Science does not just teach a person to create new forms of inanimate and living organization of matter from the passive material of nature, but it will open up (in the future) a high degree of 
perfection of the form of creative evolution of the biosphere itself. It is in the world of scientific and pedagogical work, in the community of scientists and teachers, that a higher level, that is more harmonious than the present one, of development of spirit and matter, thought and Nature can be achieved. Initially, the university can and should become such a thinking-organic community. Within the walls of the university, the spirit that drives scientific knowledge has significantly transformed both the human being itself, the worldview of a person, his perception of the world, and human relations, human connections with other people, society and Nature.

Merab Konstantinovich Mamardashvili (1930-1990), one of the most original and influential Russian thinkers of the late 20th century, developed his own, largely original, philosophical and anthropological approach to science and education.

Education is an integral part of the scientific knowledge system. It solves the paramount task of transforming the spontaneous relationship of an individual and society as a whole to the natural world, the world of cultural and historical experience, various social formations and communities, and finally to human personalities on the basis of the accumulation and deep assimilation of knowledge that postulates the experience of human existence and makes it feasible in practice. Mamardashvili (1990a) focuses on the fact that it is precisely thanks to a human phenomenon that something is being done in the world that cannot happen in a different way, other than culturally. The world as a picture of reality each time gets its expression and registration in the knowledge systems that structure it, as if reintroducing itself, penetrating deeper into its own limits and meanings of being. "By this I want to say that an innovative cognitive act is accomplished only by containing, at a point, the conditions and internal connections of science as a whole. And in this sense, knowledge is all in the present, irreversibly excluding the possibility of restoring the world to its former state".

Science, which is irreversible and having an "effect of the present", introduces drama and dynamics into human existence, both individual and social. On the one hand, science requires overcoming any available human experience, and on the other, it is the personification of this reversibly organized experience. Science has an actual meaning in the source of its cognitive power or "intellectual ability". This transpersonal, always real living sense distinguishes science, thinking, for example, from ideology. This cannot but reflect on the processes that determine the existence of higher education, education in general, which, by introducing students to cultural density, or, in the terms of Mamardashvili (1990a, 1990b), the "corporeality" of science as a kind of education, should at the same time aim them mainly 
on the implementation of intellectual transformations that make up the essence of the physicality of science. Therefore, education in the first place is to be considered as a process of comprehension of a living truth: truth that is not only representing already established, ready-made forms of knowledge, that allow a person to carry out various types of practical activities more or less successfully, but mainly open the curtain on the still unknown and, nevertheless, vitally important, namely the truth that nicknames and calls out the man and thus calling out existence itself from the oblivion. This process should mainly determine the very essence of educational technology.

For Mamardashvili (1990a), both science, taken as cognition and, accordingly, a space from which world laws (physical, biological, social, etc) can "speak out, or, if you like, happen, be noticed, give in to discretion", and education, which is capable of creatively assimilating and introducing scientific knowledge into various social practices of a person, is associated not only with a person, but with a "possible person". The prospect of knowing something in the world and the efficiency of education depend on whether individuals are those who have overcome their naturalness, that is, the natural, animal origin in themselves, who, and to what extent, or qualitatively, has passed their "rebirth" in culture. The cognitive goals and values of science - pursuit of truth and universal knowledge that would not depend on a person, as well as its theoretical and practical development in educational processes, especially in higher education - are achievable only because the science and education themselves produce the subject of this knowledge, which is in no way committed to them, a subject who, at the same time, "never casts itself into any final image". In Mamardashvili's opinion (1990a, 1990b), it is this connection that with a possible, and not with an existing person serves as the defining moment of the realization of knowledge, the crystallization of culture and the realization of the essence and prospects of education.

In the process of education as an integral component of many cognitive processes, a person, being introduced to the universal experience of cognition, each time re-opens himself and his prospects for existence in the world, the possibilities and meanings of his own being and the whole universe; yet it is necessary to understand that a discovery like that is in many ways identical with the self-creation of man and the creation - in the process of his selfrealization in the world - of the very idea of being as central, an idea, among other things, representing main aspects, communications, relations and interactions of a person with the world and with himself. 


\section{Discussion and Conclusions}

Today the development of civilization, with its foundations being born in universities, is proceeding at an accelerating pace, and it is very important that the necessary changes are based on the principle of continuity and the preservation of great cultural traditions.

The philosophical anthropology of the $20 \mathrm{~h}$ century, as well as science reflecting on its own foundations and comprehending its actual purpose, taught us to think in a global sense and on a global scale. Therefore, when we talk about science and everything that is directly connected with it, primarily education and higher education, we must take into account this particular focus on the today's existential problems of existence. The social responsibility of scientist and teacher increases in direct proportion to the complexity of the processes taking place in culture at present and determining its specificity, processes that reflect the need for the search and approval of new, more progressive, as it seems, forms of civilizational existence and future development (in any case, it is clear that the search for such forms is necessary) and at the same time demonstrate the contradictory and multifaceted nature of the pressing problems of this development, as well as the importance of profoundly mindful decision-making. That is why today, when, one might say, the structure and the matrix foundation itself has become almost the central component of the planetary system of the world of human technogenic existence, it is so important to pay attention to the development of the educational sphere of culture, the expansion of the range of educational disciplines (especially the humane ones) and the areas of its impact on society, as well as the to the widespread deepening of the humane component of human existence. On the contrary, the destruction of the scientific and educational chronotope of human existence, or even the recognition of serious violations of its functioning, will result in many negative influences, destructive and, possibly, irreversible effects on a person, the world, and culture. There is no talk about certain products of the harmonious development of the human person or society being subjected to negative influences, persecuted or even completely destroyed, but about the destruction of internal sources of harmony, internal conditions and possibilities of thought through a significant distortion of the outer space. As a result of this, the humanistic idea of universal development is under attack, the human principle of the world is and the culture of thought collapse, and the thought itself is at risk. It should be remembered that "the man is not entirely in a man. We approach ourselves from afar, form a distant length. And, by the way, 
during this time (and in space), while we go towards ourselves, a lot can happen, and finally we can fail..." (Mamardashvili, 1990b). With this circumstance, both salutary something destructive for man and the world, there is a real threat to existence, and, at the same time, the great hope.

\section{Contribution of the authors:}

Oleg G. Arapov - development of the methodology; critical analysis of the materials and formulation of the primary conclusions; V. Vernadsky, N. Moiseev, M. Mamardashvili

Elmira A. Arapova - development of methodology; formulation of the basic research concept; S. Hessen

Olga A. Volnyakova - scientific advising; development of the methodology for content analysis; critical analysis and formulation of the primary conclusions; D. Mendeleev

Denis V. Solodukhin - search for analytical materials in Russian and foreign sources; editing the final version of the text; I. Ilyin, A. Ukhtomsky

\section{REFERENCES}

1. Arapov, O., Arapova, A., Volnyakova, O., Ivanova, A., Krivolapova, J., \& Solodukhin, D. (2016). Philosophy as Rational Knowledge. Indian Journal of Science and Technology, 9(46), 449-460.

2. Arapov, O.G., Arapova, E.A., Volnyakova, O.A., \& Solodukhin, D.V. (2018). Philosophical Problems of Education in the Russian Natural Scientific Thought. Russian Technological Journal, 6(6), 84-100.

3. Bendixen, C., \& Jacobsen, J.C. (2017) Nullifying Quality: The Marketisation of Higher Education. Quality in Higher Education, 23(1), 20-34.

4. Berbegal-Mirabent, J., Mas-Machuca, M., \& Marimon, F. (2018). Is Research Mediating the Relationship between Teaching Experience and Student Satisfaction? Studies in Higher Education, 43(6), 973-988.

5. Conceição, C.P., Ávila, P., Coelho, A.R., \& Costa, A.F. (2019). European Action Plans for Science-Society Relations: Changing Buzzwords, Changing the Agenda. Minerva, 58, 1-24. 
6. Faber, C., Hardin, E., Klein-Gardner, S., \& Benson, L. (2014). Development of Teachers as Scientists in Research Experiences for Teachers Programs. Journal of Science Teacher Education, 25(7), 785-806.

7. Gagaev, A.A, \& Gagaev, P.A. (2008). Russian Philosophical and Pedagogical Teachings of the XVIII - XX Centuries. Penza.

8. Gharawi, M.A., Bidin, A., \& Choo, K.A. (2020). Malaysian Learners' Preferences-Based Profile Model towards Adaptive Massive Open Online Courses. Journal of Southwest Jiaotong University, 55(1). http://jsju.org/index.php/journal/article/view/480

9. Halversen, C., \& Tran, L.U. (2010). Communicating Ocean Sciences to Informal Audiences: A Scientist-Educator Partnership to Prepare the Next Generation of Scientists. The New Educator, 6(3-4), 265-279.

10. Hammarfelt, B., de Rijcke, S., \& Wouters, P. (2017). From Eminent Men to Excellent Universities: University Rankings as Calculative Devices. Minerva, 55, 391-411.

11. Hessen, S.I. (1995). Introduction to Applied Philosophy. Moscow: Shkola-Press.

12. Hicks, D., \& Holbrook, J.B. (2019). A Cartography of Philosophy's Engagement with Society. Minerva, 58, 25-45.

13. Ilyin, I.A. (2017). The Path to Evidence. Moscow: EKSMO-Press.

14. Jusuf, E., Herwany, A., Kurniawan, P.S., \& Gunardi, A. (2020). Sustainability Concept Implementation in Higher Education Institutions of Indonesia. Journal of Southwest Jiaotong University, 55(1). http://jsju.org/index.php/journal/article/view/488

15. Lazutina, T.V., Tempel, Yu.A., \& Tempel, O.A. (2017). Philosophy's Role as a Form of Worldview in Mastering Competences by Students of the Technical Specialisations in the Modern Russia's Higher Education System. Integration of Education, 21(1), 19-34.

16. Lobanova, O.B. (2007). Russian Pedagogical Thought of the Late XIX - Early XX Century on the Pedagogical Experience Core. Modern Problems of Science and Education, 1, 54-56.

17. Löfström, E., \& Pyhältö, K. (2017). Ethics in the Supervisory Relationship: Supervisors' and Doctoral Students' Dilemmas in the Natural and Behavioural Sciences. Studies in Higher Education, 42(2), 232-247.

18. Mamardashvili, M. (1990a). Science and Culture. Moscow: Progress.

19. Mamardashvili, M. (1990b). Thought in Culture. Moscow: Progress.

20. Margolis, J. (2007). Improving Relationships between Mentor Teachers and Student Teachers: Engaging in Pedagogy of Explicitness. The New Educator, 3(1), 75-94.

21. Masuda, A. (2014). “They're Shocked That I'm Doing Research!”: Supporting an Early Career Teacher's Inquiry in Teaching Informative Writing. The New Educator, 10(3), 201-221.

22. McLean, N., \& Price, L. (2019). Identity Formation among Novice Academic Teachers - A Longitudinal Study. Studies in Higher Education, 44(6), 990-1003. 
23. Mendeleev, D.I. (1905). The Cherished Thoughts. Moscow: Mysl.

24. Morrison, J., \& Estes, J. (2007). Using Scientists and Real-World Scenarios in Professional Development for Middle School Science Teachers. Journal of Science Teacher Education, 18(2), 165-184.

25. National Research Council. (1996). The Role of Scientists in the Professional Development of Science Teachers. Washington, District of Columbia: National Academies Press.

26. National Research Council. (2009). Learning Science in Informal Environments. People, Places, and Pursuits. Washington, District of Columbia: The National Academies Press.

27. Ryan, M., Taylor, M., Barone, A., Pesca, L.D., Durgana, S., Ostrowski, K., Piccirillo, T., \& Pikaard, K. (2017). Teacher as Researcher, Teacher as Scholar, and Teacher as Leader. The New Educator, 13(2), 102-116.

28. Saxman, L.J., Gupta, P., \& Steinberg, R.N. (2010). CLUSTER: University-Science Center Partnership for Science Teacher Preparation. The New Educator, 6(3-4), 280-296.

29. Scoles, J., Huxham, M., Sinclair, K., Lewis, C., Jung, J., \& Dougall, E. (2019). The Other Side of a Magic Mirror: Exploring Collegiality in Student and Staff Partnership Work. Teaching in Higher Education. https://www.tandfonline.com/doi/full/10.1080/13562517.2019.1677588

30. Ukhtomsky, A.A. (2008). The Face of Another Person. Saint Petersburg: Ivan Limbakh Publishing House.

31. Vasilevska, D., Rivza, B., Alekneviciene, V., \& Parlińska, A. (2017). Analysis of the Demand for Distance Education at Eastern and Central European Higher Education Institutions. Journal of Teacher Education for Sustainability, 19(1), 106-116.

32. Vernadsky, V.I. (1993). Autotrophy of Mankind. Russian Cosmism: Anthology of Philosophical Thought. Moscow: Pedagogy-Press.

33. Vernadsky, V.I. (2010). Selected Works. Moscow: Rosspen.

34.Williams, R.J.P. (1991). Science in Universities: Teaching, Research and Autonomy. Studies in Higher Education, 16(1), 15-22.

\section{SOBRE OS AUTORES:}

\section{Olga A. Volnyakova}

Candidate of Philosophy, Professor, Russian Technological University, Institute of Innovative Technologies and Public Administration, Department of Social \& Humanitarian Sciences MIREA (78, Vernadskogo Pr., Moscow 119454, Russia).Email: olgavolnyakova@yandex.ru (iD http://orcid.org/0000-0002-8086-1673 


\section{Oleg G. Arapov}

Candidate of Philosophy, Associate Professor, Peoples' Friendship University of Russia (RUDN University), Faculty of Humanities and Social Sciences, Department of Social Philosophy, Moscow. Email: oleg.g-arapov@yandex.ru

(iD) http://orcid.org/0000-0002-8107-9958

\section{Elmira A. Arapova}

Candidate of Philosophy, Associate Professor, Russian Technological University, Institute of Innovative Technologies and Public Administration, Department of Social \& Humanitarian Sciences MIREA (78, Vernadskogo Pr., Moscow 119454, Russia). Email: elmira.a.arapova@yandex.ru

(iD http://orcid.org/0000-0001-9310-5896

\section{Denis V. Solodukhin}

Candidate of Philosophy, Associate Professor, Russian Technological University, Institute of Innovative Technologies and Public Administration, Department of Social \& Humanitarian Sciences MIREA (78, Vernadskogo Pr., Moscow 119454, Russia). E-mail: denis.v.solodukhin@yandex.ru

iD http://orcid.org/0000-0002-0139-3358 